\title{
Effectiveness in risk assessment — a comparison of perceived and realised risk from project concept to construction and operation
}

\author{
L. Murray Klohn Crippen Berger Ltd, Canada \\ H. McLeod Klohn Crippen Berger Ltd, Canada \\ G. Suter Klohn Crippen Berger Ltd, Australia
}

\begin{abstract}
Tailings and waste rock disposal is rightly seen as one of the major short and long-term risks associated with mining. High profile catastrophic failures of dams and waste dumps make international headlines all too often. Risk assessments, often done in a workshop format, are one of the main tools whereby designers, operators and owners seek to identify and mitigate hazards and their associated consequences.
\end{abstract}

The authors have been undertaking risk assessments, using failure modes and effects analysis (FMEA), on mine waste disposal projects since the early 1990s, in many different environments and in many different parts of the world. From that collective experience, this paper looks back at the risk assessments for a series of case histories where designs have developed into built waste management facilities. With the benefit of hindsight the paper reviews what has worked, what has not worked and whether serious hazards had gone unnoticed.

The selected case histories involve mine developments in remote locations, in high rainfall, high seismic and weak soil environments. Because the sites are in hazardous environments, the operations have been exposed to most of the classic tailings storage facility risks, indeed the sites have experienced some large events without undue damage. The design risks are relatively easily quantifiable and with careful consideration can be minimised and allowed for. The paper also identifies some 'soft' risks, for example management and project controls. The importance of having a management team that understands the design limitations and is committed to the safe and long-term design of the structures is immensely important. An example is also given as to how FMEA is used in business practice.

Conclusions are presented which may help others in dealing with risk and uncertainty in hazardous environments.

\section{Introduction}

There are many approaches to undertaking risk assessments and the methods can range from the simplistic to highly complex numerical methods. Steve Vick, in his excellent book, 'Degrees of Belief' (2002), captures the debate about the range of approaches and expectations from risk assessments and the range of notions about the probability of bad things happening. One school of thought seeks to achieve an objective insight into the probability of an event occurring while others take a more subjective approach based on judgement. The title of Vick's book is a clue to his conclusion, that ultimately, however good the mathematics look, assessment of risk is heavily founded in judgement.

In commencing preparation of this paper, the common practice in Klohn Crippen Berger (KCB) was reviewed and the experience in the company is that risk assessment based on judgement is the most appropriate approach. There is obviously an important place for analysis to assist in informed judgement, but collective judgement based on experience is a powerful tool and one that can be readily understood by people of varying backgrounds when properly documented. The authors have been conducting risk assessments in a formal way since the early $1990 \mathrm{~s}$, but had not reviewed that experience to see how effective the predictions were. This paper sets out to investigate if the authors' approach, which involves input from many mining clients, is effective. 
Failure Modes and Effects Analysis (FMEA) is the tool most commonly used by the authors for structured recording and presentation of risk assessment processes. The FMEA approach is very useful for complex systems and the examples in this paper concentrate on FMEA. In some cases, where there is a well-defined problem, such as a potential seepage failure for a single structure, the use of the event tree methodology may be preferred. However, for multi component facilities with different risk profiles at different life stages the FMEA has proven the most useful approach.

The methodology for FMEA has evolved through use over the years and the current preferred method is described in the following section. Some of the examples, which were initially done many years ago, may have used different formats and these original formats are maintained in the case histories, however the basic approach has been unchanged over the years.

\section{$2 \quad$ Failure modes and effects analysis}

FMEA is a structured qualitative risk assessment methodology that was developed and refined in response to the Bhopal and Challenger disasters. The methodology has been used in a wide variety of applications and is described in numerous papers. The standard FMEA has been modified by the authors to provide a clearer framework for risk management, and this approach is commonly used to assess concerns related to mine tailings dams. The assessment is carried out in a workshop environment. Attendees at the workshop typically include the following:

- Owner or client

- Designers

- Contractors or operators

- Risk assessment team

- Representatives of environmental regulatory agencies or non government organisations (NGOs)

- Risk review board (optional).

The workshop typically takes two to three days to complete and may be repeated in two or three additional workshops to allow further feedback from participants and the other parties. During the workshop, each component of the facility is discussed, and a brainstorm session of what can go wrong (i.e. the hazards) is carried out. The failure modes and the effects of failure are assessed. Each failure mode is then assigned likelihood, consequence, etc.

For the analysis, it is necessary to have a clear understanding of what is being assessed. Usually this is achieved by listing the main project components and sub-components. Judgement is needed to achieve a meaningful but not overly complex subdivision into components. Each component is then treated as a 'free body' unit that is 'tested' for each identified hazard. One weakness of FMEA is that it does not easily model inter-dependency of failure modes, if that is important another method such as an event tree should be considered.

For FMEA, an identity number is assigned for each component and sub-component. For example, a mine tailings facility could have the following main components and sub-components:

- 100 Series Dam: filters (110), drains (120), fill (130), foundation (140), impervious zone (150), etc.

- 200 Series Impoundment: decants (210), spillways (220), diversion channels (230) tailings beach (240), reservoir slopes (250), etc.

- 300 Series Water Reclaim: pump barges (310) and pump back systems (320)

- 400 Series Tailings Distribution: thickeners (410), dewatering plants (420), tailing pipelines (430), cyclone stations (440), etc.

- 500 Series Closure: covers (510), closure spillway (520), water treatment plants (530), final dam (540), etc. 
The stage of the project is noted for each failure mode, since the duration of the risk exposure is important in comparing risks between different project stages. The main project stages, and typical time frames, are summarised as follows (actual time frames vary from those shown and need to be adjusted on a project basis).

- Construction (C)

- Operation (O)

- Decommissioning (D)

- Post-mining land use (P)
1 to 3 years

10 to 30 years

10 years

1,000 years.

Because this paper reviews FMEA case histories, the time frame is around 20 years or less and does not cover long-term post mining land use.

\subsection{Likelihood of failure}

The likelihood or probability of failure is ranked on a five level scale, which is based on the annual probability of failure. Table 1 summarises the five levels and gives typical corresponding examples. It is necessary that workshop participants are consistent in applying the likelihood of the failure mode occurring.

Table 1 Summary of likelihood criteria

\begin{tabular}{|c|c|c|c|}
\hline Level & $\begin{array}{l}\text { Annual } \\
\text { Probability }\end{array}$ & $\begin{array}{l}\text { Return Period } \\
(\mathrm{yr})\end{array}$ & Typical Examples \\
\hline Negligible (N) & $<10^{-6}$ & $>1$ million & Doubt it could happen. \\
\hline Very low (VL) & $10^{-4}$ to $10^{-6}$ & $\begin{array}{l}10,000 \text { to } \\
1 \text { million }\end{array}$ & $\begin{array}{l}\text { Unlikely to happen, lightning death, probable } \\
\text { maximum flood, maximum credible earthquake. }\end{array}$ \\
\hline Low (L) & $10^{-2}$ to $10^{-4-}$ & 100 to 10,000 & $\begin{array}{l}\text { Could happen: cancer, suicide, intermediate } \\
\text { earthquakes \& floods. }\end{array}$ \\
\hline Moderate (M) & $10^{-1}$ to $10^{-2}$ & 10 to 100 & $\begin{array}{l}\text { Has or will happen: open pit slope failures, } \\
\text { concrete degradation, death in a vehicle accident. }\end{array}$ \\
\hline $\operatorname{High}(\mathrm{H})$ & $>10^{-1}$ & $<10$ & $\begin{array}{l}\text { Happens regularly: pump shutdown, pipeline } \\
\text { breakage, vehicle accidents, QA/QC excursions. }\end{array}$ \\
\hline
\end{tabular}

\subsection{Consequence of failure}

The consequences of failure could be quantified with a wide variety of parameters; however, it is advantageous to limit the number of consequences to allow workshop participants to focus on key issues. A proposal for a standard set of consequences is presented herein, along with preliminary criteria for each level of consequence. The consequences are ranked on a five level scale and need to be reviewed and developed on a project-by-project basis. The level of detail will vary depending on the complexity of the project, the level of studies and the potential impacts. It is, however, necessary that the workshop participants use the criteria consistently to allow comparison of risks. The three main areas of risk are typically the water environment, the biophysical environment and the socioeconomic environment. Typical consequence criteria for the noted areas of risk for a tailings dam are shown in Table 2, however, site-specific consequence criteria should be developed for each project. 
Table 2 Summary of consequence criteria

\begin{tabular}{|c|c|}
\hline Category & Consequence - Water Quality \\
\hline Negligible (N) & No detectable changes relative to 'background' conditions. \\
\hline Low $(\mathrm{L})$ & $\begin{array}{l}\text { Minor changes, occasional exceedance of water quality standards }{ }^{1} \text {. Minimal impacts on } \\
\text { aquatic life, less than } 20 \% \text { mortality }^{2} \text {. All groundwater degradation is 'onsite'. }\end{array}$ \\
\hline Moderate (M) & $\begin{array}{l}\text { Exceedance of water quality standards on a regular basis; sediment load between twice } \\
\text { and five times baseline. Localised, short term, reversible impact on aquatic life with } \\
20 \text { to } 50 \% \text { mortality. Sulphate concentrations between } 500 \mathrm{mg} / \mathrm{L} \text { and } 1,000 \mathrm{mg} / \mathrm{L}^{3} \text {. } \\
\text { Potential for baseline groundwater degradation in offsite wells to (for example) fall } \\
\text { from clean to drinking water standards }{ }^{4} \text {. }\end{array}$ \\
\hline $\operatorname{High}(\mathrm{H})$ & $\begin{array}{l}\text { Up to } 10 \text { times water quality standards. Widespread, long-term impact on aquatic life } \\
\text { with } 50 \text { to } 90 \% \text { mortality. Sediment load between five and } 100 \text { times baseline. Sulphate } \\
\text { concentrations between } 1,000 \text { and } 10,000 \mathrm{mg} / \mathrm{L} \text {. Potential for groundwater degradation } \\
\text { in offsite wells to fail drinking water standards }{ }^{4} \text {. }\end{array}$ \\
\hline Extreme $(\mathrm{E})$ & $\begin{array}{l}\text { Over } 100 \text { times water quality standards. Severe, potentially irreversible impact on } \\
\text { aquatic life with over } 90 \% \text { mortality. Sediment loads greater than } 100 \text { times baseline. } \\
\text { Sulphate concentrations between } 1,000 \text { and } 10,000 \mathrm{mg} / \mathrm{L} \text {, with sustained depressed } \mathrm{pH} \\
\text { and elevated metals present. Groundwater degradation in offsite wells to concentrations } \\
\text { in excess of } 100 \times \text { drinking water standards. }\end{array}$ \\
\hline Category & Consequences - Biophysical \\
\hline $\mathrm{N}$ & No measurable impact. \\
\hline $\mathrm{L}$ & Minor impact on the habitat, release of up to $10,000 \mathrm{t}$ tailings/waters. \\
\hline M & $\begin{array}{l}\text { Significant, reversible impact on habitat, release of } 10,000 \text { to } 100,000 \mathrm{Mt} \text { of } \\
\text { tailings/water. }\end{array}$ \\
\hline $\mathrm{H}$ & Significant irreversible habitat impact, release of 100,000 to $1 \mathrm{Mt}$ of tailings/water. \\
\hline $\mathrm{E}$ & Catastrophic impact, release of $>1 \mathrm{Mt}$ of tailings/water. \\
\hline Category & Consequences - Socioeconomic \\
\hline $\mathrm{N}$ & No measurable changes. \\
\hline $\mathrm{L}$ & Less than $\$ 1$ million in costs, affects $<10$ people, local public image concern. \\
\hline M & $\$ 1$ to 10 million in costs, affects 10 to 100 people, provincial public image concern. \\
\hline $\mathrm{H}$ & $\begin{array}{l}\$ 10 \text { to } 50 \text { million in costs, affects } 100 \text { to } 1,000 \text { people, national public image concern. } \\
\text { Loss of life. }\end{array}$ \\
\hline $\mathrm{E}$ & $\begin{array}{l}>\$ 50 \text { million in costs, affects }>1,000 \text { people, international public image concern. Loss } \\
\text { of multiple lives. }\end{array}$ \\
\hline $\begin{array}{ll}\text { tes: } & \text { Water qu } \\
\text { 2. } & \text { Impact or } \\
\text { 3. } & \text { Sulphate } \\
\text { 4. } & \text { Depends }\end{array}$ & $\begin{array}{l}\text { as defined by permit limits, company standards, or World Bank guidelines for receiving water quality. } \\
\text { atic life is quantified by bioassay tests to determine the mortality rate. } \\
\text { entrations are used as an indicator of acid rock drainage. } \\
\text { aseline water quality. Drinking water standards as defined by permit limits or World Bank guidelines. }\end{array}$ \\
\hline
\end{tabular}

\subsection{Confidence level}

The level of confidence in the likelihood and/or consequences is illustrated on a three level scale as follows:

- Low (L). Do not have confidence in the estimates, potential for high variability.

- Moderate (M). Have some confidence in the estimates and moderate variability.

- High $(\mathrm{H})$. Have confidence in the estimates and low variability. 


\subsection{Compensating factors}

For each failure mode and effect there may be compensating factors that could be introduced to reduce the risk. The compensating factors could include some the following general components:

- Specific QA/QC programs to ensure compliance with design.

- Additional engineering or scientific studies to increase level of confidence.

- Operational monitoring.

- Civil works to increase factor of safety.

- Community liaison and community development programs to reduce public perception and reduce risks by incorporating 'local' knowledge.

\subsection{Post compensation risks}

After compensating factors are applied the level of risk may be reduced. The failure mode is then assigned a revised likelihood, assuming the same consequence. The confidence level that the compensating factor is appropriate, technically feasible, and cost effective, is assessed to reflect the level of certainty that the compensating factors will be applied and will be effective.

\section{$3 \quad$ Risk assessment}

Risk assessment involves a 'binning' (screening) process to identify the higher risk items. The criteria for binning consider the likelihood and consequence of failure, as well as the time exposure of the annual probability. The resulting risks are plotted on a 'Risk Review Chart', an example of which is shown in Figure 1. The chart can also be used to illustrate which risks could be considered the responsibility of corporate, engineering, supervisory or labour staff. Typical criteria for binning involve a number of risk levels, the following example has four risk levels as follows:

- Level 1: Risks with high likelihood and extreme consequences (H-E) are classified as 'fatal flaws'. These risks are unacceptable and mean that a new design must be generated or the project should not go ahead.

- Level 2: Risks with high likelihood and high consequences $(\mathrm{H}-\mathrm{H})$; and risks with moderate likelihood and extreme consequences (M-E). These risks are of concern to senior management, shareholders and the potentially affected public. They require a high level of scrutiny and detailed risk management and contingency plans.

- Level 3: Risks with high likelihood and moderate consequences (H-M); risks with moderate likelihood and high consequences $(\mathrm{M}-\mathrm{H})$; and risks with low likelihood and extreme consequences (L-E). These risks are of the concern of senior management, engineering design and operating staff. They require a risk management plan and contingency plan.

- Level 4: Risks with high likelihood and low consequences (H-L), risks with moderate likelihood and moderate consequences $(\mathrm{M}-\mathrm{M})$ and risks with low likelihood and high consequences $(\mathrm{L}-\mathrm{H})$. These risks are of concern to the engineering design and operations staff and require operating procedures and risk management plans to adequately manage the risks.

In addition, the time exposure of the risk and the confidence factor will trigger a binning to the next highest likelihood category in consideration of the following:

- Risks with a low level of confidence will be 'binned' out as equivalent to the next highest likelihood category.

- Post closure land use risks, because of their long exposure time, will bin out as equivalent to the next highest likelihood category. 


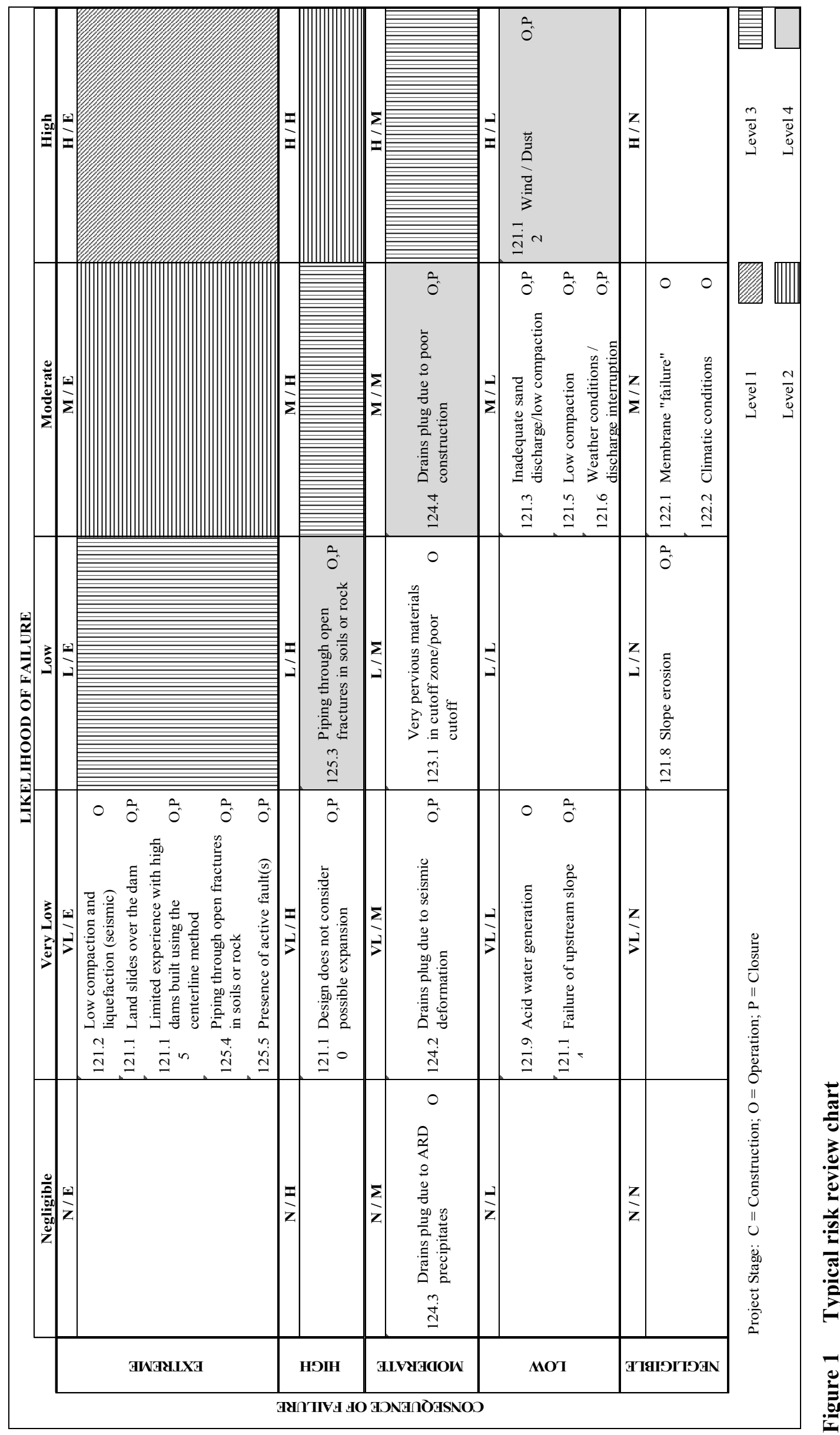




\section{$4 \quad$ Risk assessment case histories}

The authors have been involved in FMEA assessment for the selected case histories from early design stages through construction and into long-term operation. The examples are simplified for illustrative purposes and have kept faithful to the original FMEA formats that generally differ from the current preferred format discussed above. However, the basic approach is the same as currently used and the examples illustrate the effectiveness of FMEAs.

\subsection{Ok Tedi Mining Limited - Bige sand storage area}

Ok Tedi Mining Limited, located in the Western Province of Papua New Guinea (PNG), commenced a study in the mid 1990s to examine possibilities for mitigating the impact of mine sediment on the Ok Tedi and Fly River systems. The chosen solution was to dredge sand from the river and store it on the riverbanks of the Ok Tedi at Bige. The project construction started in 1998 and since that time about 180 million $t$ of sand have been removed from the river and stored on the riverbanks in engineered containment piles constructed from the dredged sand.

When the scheme was proposed during an options assessment study in 1994, almost nothing was known about the site geology or geotechnical characteristics.

The initial engineering risk assessment was reported in March 1995. For that piece of work, environmental and social issues such as potential acid rock drainage were excluded from the work scope. Key risk items identified in 1995 are shown on Table 3.

Table 3 Summary of risk assessment 1995

\begin{tabular}{|c|c|c|c|c|c|c|c|c|}
\hline \multirow{2}{*}{$\begin{array}{l}\text { Potential } \\
\text { Risk }\end{array}$} & \multirow[t]{2}{*}{ Risk Description } & \multicolumn{4}{|c|}{ Severity } & \multirow[t]{2}{*}{ Contingency } & \multirow{2}{*}{$\begin{array}{l}\text { Likelihood of } \\
\text { Success }\end{array}$} & \multirow{2}{*}{$\begin{array}{l}\text { Comments } \\
2010\end{array}$} \\
\hline & & Safety & Cost & Operations & Environment & & & \\
\hline $\begin{array}{l}\text { River } \\
\text { migration }\end{array}$ & $\begin{array}{l}\text { River avulsions } \\
\text { causes significant } \\
\text { pile erosion }\end{array}$ & $\mathrm{L}$ & $\mathrm{L}$ & M & $\mathrm{H}$ & $\begin{array}{l}\text { Careful sitting of } \\
\text { the piles }\end{array}$ & $\begin{array}{l}\mathrm{H} \\
\text { (low in } \\
\text { long-term) }\end{array}$ & No avulsions \\
\hline $\begin{array}{l}\text { Dredge pile } \\
\text { slope } \\
\text { failure }\end{array}$ & $\begin{array}{l}\text { Slope failure of } \\
\text { outer containment } \\
\text { berm }\end{array}$ & $\mathrm{L}$ & $\mathrm{L}$ & $\mathrm{L}$ & M & $\begin{array}{l}\text { Maintain flat } \\
\text { slopes }\end{array}$ & $\mathrm{H}$ & $\begin{array}{l}\text { No significant } \\
\text { slope failures }\end{array}$ \\
\hline $\begin{array}{l}\text { Barge } \\
\text { damage } \\
\text { from river }\end{array}$ & $\begin{array}{l}\text { Damage during a } \\
\text { very high flow } \\
\text { event in the river }\end{array}$ & M & M & M & $\mathrm{L}$ & $\begin{array}{l}\text { Experienced } \\
\text { crew with } \\
\text { contingency } \\
\text { plans }\end{array}$ & $\mathrm{H}$ & No damage \\
\hline $\begin{array}{l}\text { Dredge } \\
\text { location } \\
\text { ineffective }\end{array}$ & $\begin{array}{l}\text { Dredging not fully } \\
\text { effective in } \\
\text { reducing } \\
\text { aggradations }\end{array}$ & $\mathrm{L}$ & M & $\mathrm{L}$ & $\mathrm{H}$ & $\begin{array}{l}\text { Detailed } \\
\text { engineering of } \\
\text { river system }\end{array}$ & $\mathrm{H}$ & $\begin{array}{l}\text { Post dredging } \\
\text { impacts } \\
\text { significantly } \\
\text { declined } \\
\text { relative to pre- } \\
\text { dredge } \\
\text { condition }\end{array}$ \\
\hline $\begin{array}{l}\text { Dredge } \\
\text { volume too } \\
\text { low }\end{array}$ & $\begin{array}{l}\text { Dredging rate too } \\
\text { low to control } \\
\text { aggradations }\end{array}$ & $\mathrm{L}$ & M & $\mathrm{L}$ & $\mathrm{H}$ & $\begin{array}{l}\text { Selection of } \\
\text { adequate dredge }\end{array}$ & $\mathrm{H}$ & - \\
\hline $\begin{array}{l}\text { Excessive } \\
\text { erosion }\end{array}$ & $\begin{array}{l}\text { Erosion from piles } \\
\text { is significant }\end{array}$ & $\mathrm{L}$ & $\mathrm{L}$ & $\mathrm{L}$ & M & $\begin{array}{l}\text { Ongoing } \\
\text { reclamation of } \\
\text { slopes }\end{array}$ & $\mathrm{H}$ & $\begin{array}{l}\text { Reclamation } \\
\text { and land } \\
\text { management } \\
\text { controls erosion }\end{array}$ \\
\hline
\end{tabular}


Lessons learned: After 12 years of operation, none of the above issues has resulted in significant difficulties to the project. However, soon after the Bige storage project was initiated, the dredged material was recognised as being potentially acid forming (PAF). This has been a major focus and cost to the project since about the year 2000 .

Although mitigation of the acid rock drainage (ARD) has been a major focus for the mine, the sand storage at Bige has made a positive contribution to managing the mine area PAF material, by providing a single site storage area for covering and treating material and also providing a site for storage of pyrite tailings recovered from the mill.

A significant lesson from the 1995 risk assessment is to get as broad a range of people involved as possible and not to set the scope too tightly in the initial stages.

\subsection{Hidden Valley Mine - Hamata tailings storage area}

The Hidden Valley gold prospect has been studied by a series of owners as a potential large-scale open pit mine since the mid 1980s. The mine went into production in 2009 and is the first major mine in PNG to store tailings in a conventional on land containment. KCB became involved in 1996 and prepared various risk assessments. The first assessment in 1997 simply listed potential hazards since little was known about the site. A second assessment in 2006 was more comprehensive as by that time the project had progressed to the point where construction had commenced.

In 1997, the major hazards identified were (comments in italics added in 2010 for this paper):

1. Potential shortfall in storage if the mine tonnage increased, if topography was inaccurate, or assumed deposit density was over estimated; topography is now known to have been relatively accurate but revised data did still indicate a potential shortfall, and concerns over ultimate storage capacity remain.

2. Lack of suitable material from Hamata pit to build dams, both the volume and quality of pit run materials were questioned; this remains a concern.

3. Water management was seen to be a hazard related to construction diversions, dam overtopping etc; this has largely been avoided in the design and construction by forming diversions around the TSF.

4. Dam and reservoir margin stability; these have proven not to be a major concern.

5. Constructability due to high rainfall, weak soils and remote site; these continue to be a major focus as the dams are raised, but have so far been managed.

In 2006, the following major hazards were identified as in Table 4. 


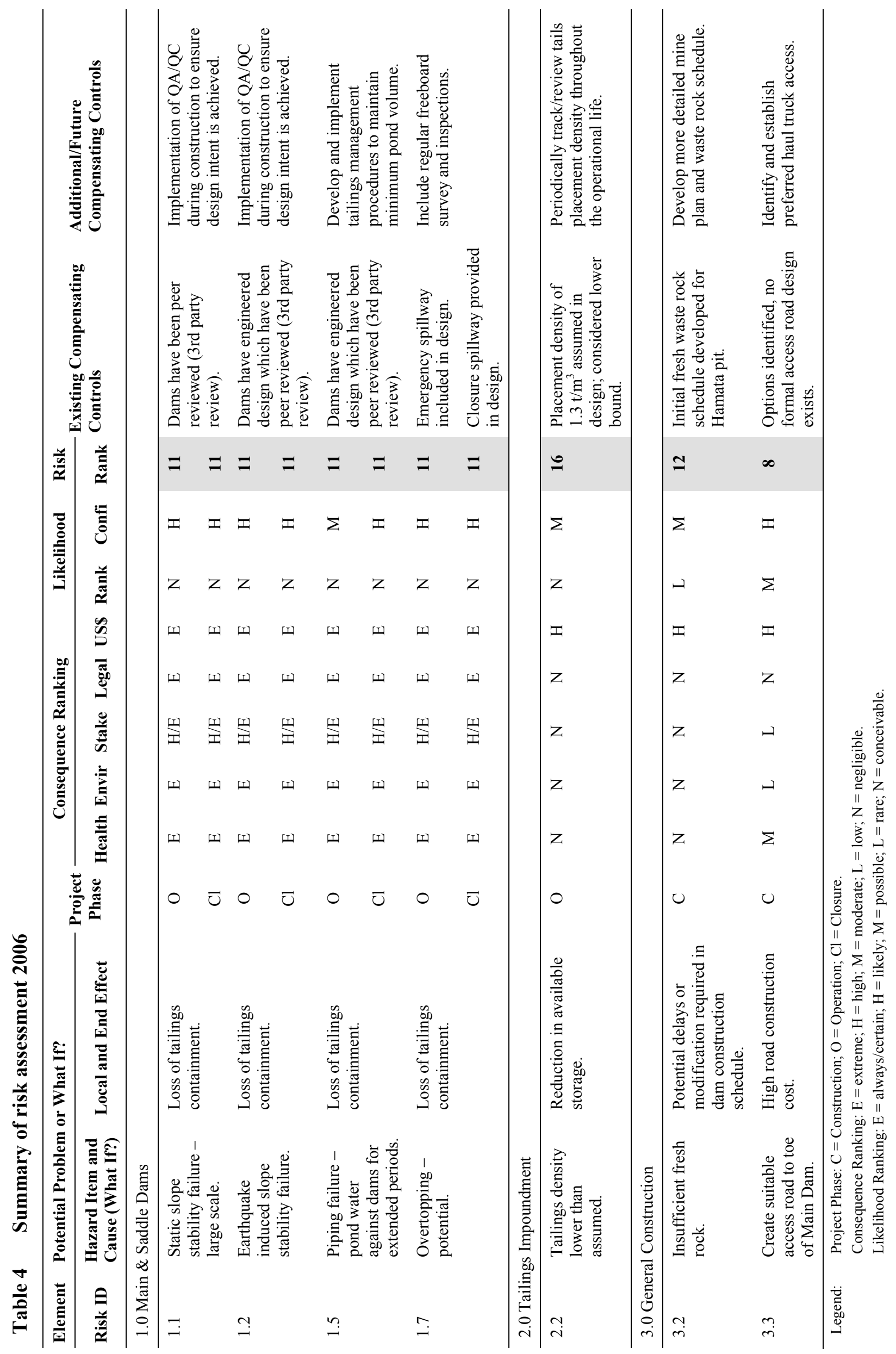


Lessons learned: Although no new risks/hazards have come to light; the main risks which were constrained by the site physical conditions, rather than long-term events such as floods/earthquakes, remain a problem. Volume of storage, suitability of pit waste for construction and constructability issues remain concerns for the mine. Several hazards such as the difficulty accessing the downstream toe of the dam were overcome by good construction planning.

One of the main issues experienced in construction of the dam was the lack of competent rock for construction. This risk was identified during the 1997 risk assessment and was assigned a Low probability in 2006 due to the presence of a rock schedule that was developed for the Hamata pit (a mine production open pit adjacent to the dam) which identified sufficient competent rock for this purpose. This schedule was updated prior to the rock being required for the dam and it was found that there would now not be suitable rock available for construction until well past the time it was required. While this has not caused delays to the commissioning of the mine and the deposition of tailings into the TSF, a significant redesign of the main dam was required to allow for the use of alternate construction materials, different from the original design expectations.

This highlights the potential shortcomings of this risk assessment in terms of the data available at the time of the assessment. This also highlights the importance of flexibility in design to allow for such significant, rapid changes in actual site conditions.

The highest risk identified for the dam in 2006 was the ability to safely access the downstream toe of the main dam due to the steep terrain and location of the pit and other infrastructure. The ability to properly assess a suitable road access prior to construction was hampered by the steep, heavily forested terrain of the dam area. Once construction began and the land was cleared, the full scope of the problem came to light. A road route was eventually determined, although on the opposite side of the gorge to what was originally thought to be the possible route. Road access would generally not be considered to be such a high risk, usually being outweighed by more high profile design features, however, in this case the likely safety issues and high cost of the road resulted in a high risk ranking. As such, effort was made early in construction to find the best route to access the gorge area and no delays were experienced due to the toe access road construction.

\subsection{Business risk}

The FMEA analysis can be applied to almost any problem.

$\mathrm{KCB}$ also uses the FMEA process for assessing business risk for major projects. This process allows a more definitive assessment of the success of the FMEA process because the risk window has an end date at the end of the project. Unlike the tailings dams discussed above which have to survive in perpetuity after closure.

In 2003/04 KCB commenced design of a 1,000 MW hydroelectric overseas project for a foreign owner. KCB was concerned about financial risk on the project. Components identified that could have impacted the financial performance included the lenders, owner, contractor, the contract; insurance policies; KCB project management and corporate management, along with their respective procedures and practices. For the purposes of the FMEA, loss was identified as a revenue deficit relative to the corresponding budget item.

A portion of the business risk FMEA is reproduced on Table 5.

This assessment found that the largest exposure came from risks associated with project management issues (reproduced in the Table 5). During the risk assessment program it was found that many of the business risks were limited by insurance or loan guarantees or were less likely to occur than a project management mistake during a fast tracked project. The attendees were asked to give a high/low estimate of probability of loss and a best guess (in parentheses). One third of the estimated potential risk loss from all project risks came from the hazard that the construction would outpace the design, which could cause significant re-work not reimbursable under the lump sum contract.

Lessons learned: Although not complete the project has not suffered a write-off. It is not possible to tell how the risk assessment contributed to this, but it is likely that focus of the design/management team on the perceived major risks contributed to this outcome. 


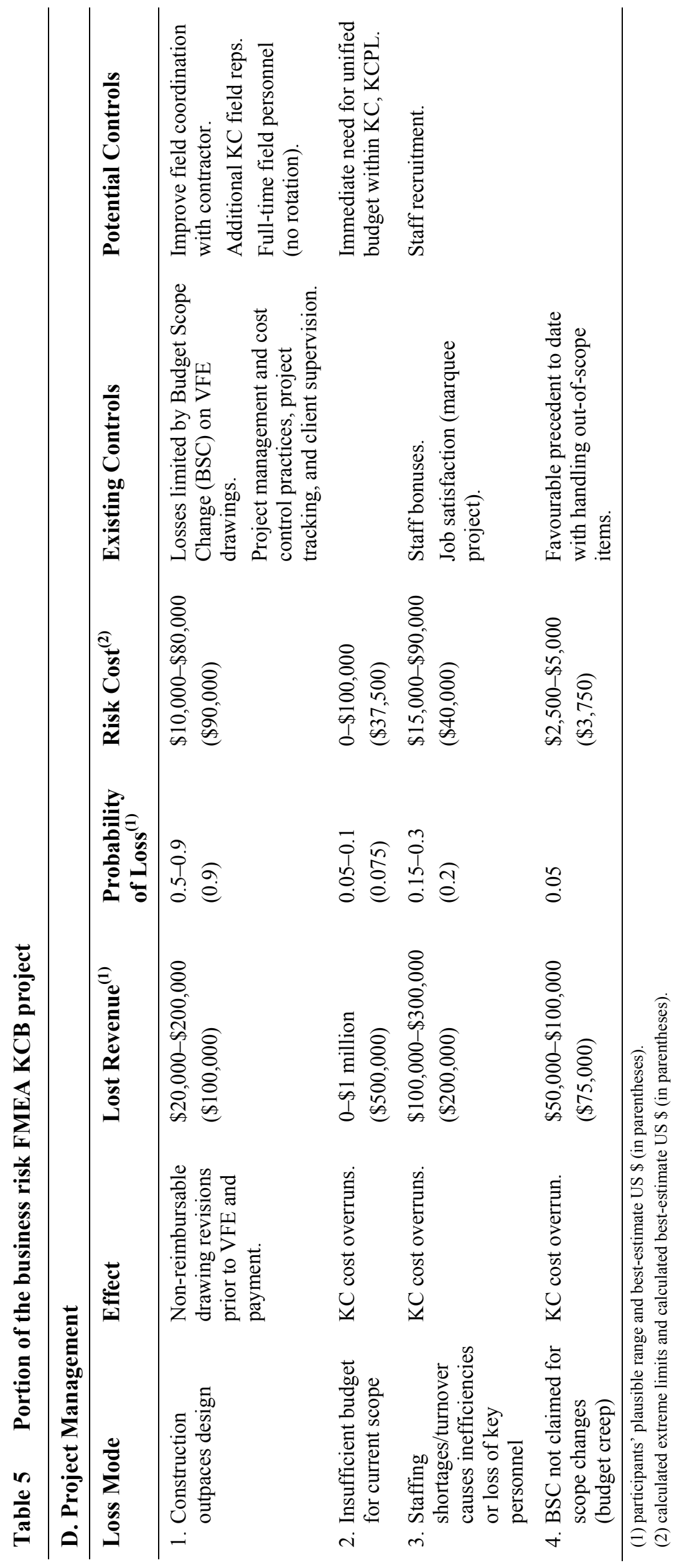




\section{Conclusions}

The overall risk approach focussing on judgement based application has been described, along with application to two tailings disposal sites and a business risk assessment.

A review of the case histories, up to 20 years after the original risk assessment, suggests that:

- The FMEA process using a broad panel of experts and informed practitioners has been successful in identifying hazards.

- The relative importance of risks during the FMEA can be incorrectly estimated due to uncertainties or lack of information. Regular updates of the FMEA are required as project information becomes more certain.

- Risks that are constrained by site characteristics such as topography are likely to remain a problem.

- Risk mitigation is an on-going concern that requires management commitment for enduring identification and implementation of adequate risk reduction strategies.

- Terms of reference for the risk assessment panel should not be too tightly constrained otherwise important risks could be overlooked.

Overall, the FMEA process appears to have been a successful approach to risk identification and mitigation.

\section{Reference}

Vick, S.G. (2002) Degrees of Belief, ASCE Press American Society of Civil Engineers, Reston, Virginia, USA. 